\title{
The life and times of women's policy machinery in Australia ${ }^{1}$
}

\author{
MARIAN SAWER
}

Historically in Australia women have been policy shapers as well as policy takers and have called on the state to promote social reform and equal opportunity. This was the path that led to the appearance of 'femocrats' in government in the 1970s and 1980s, with a mandate to achieve more gender equality policy outcomes. Australia became well known for its femocrats, a term that Australia gave the world, and for their innovations in governance. However, at the same time another group was increasing its policy influence - the economic rationalists, who believed that intervention in the market to promote equity or other social goals was counter-productive.

This resurgence of market liberalism preceded, but was reinforced by, the election of conservative governments in the 1990s. To varying degrees these governments had engaged in their election campaigns in populist discourse concerning the excessive power of special interest groups over government and the need to end regimes of 'political correctness'. In practice this often meant views that 'feminism had gone too far' in its policy influence and that the pendulum needed to be readjusted in favour of men. Not surprisingly, such views were unfavourable to the kind of close analysis of the gender effects of policy for which Australia had been noted.

In this chapter, I survey the impact of these discursive shifts on women's policy machinery, primarily at the federal level but with some broader comments relating to subnational levels of government (states and territories). The sources for this chapter include a survey of federal women's policy units conducted in May-June 1998 and outcomes of a workshop involving state and territory women's advisers in February 1998. 


\section{The Australian model of women's policy machinery}

It should be noted that Australia has a Westminster system of responsible government, deriving from the United Kingdom but complicated by federalism and strong upper houses. There are six states and two territories, in addition to the federal level of government (known as the Commonwealth government, not to be confused with the British Commonwealth). A historic two-party system, made up of the Australian Labor Party on the one hand and a conservative coalition of various political parties on the other, has been diluted by the appearance of minor parties and Independents holding the balance of power, both at Commonwealth and at state and territory levels of government. This development has been facilitated by the use of proportional representation in six of Australia's houses of parliament, but has not been restricted to chambers elected in this way.

The first Australian Women's Adviser was appointed by Labor Prime Minister Gough Whitlam in 1973. At her first press conference she articulated what was to be the central focus of the Australian model - the need to audit all Cabinet submissions for their impact on women. The functional priority given to gender audit of all policy meant in turn a related structural focus on locating women's policy machinery within the central policy coordinating agency of government. In Australia, this is the Prime Minister's, Premier's or Chief Minister's Department, depending on the level of government.

One important aspect of the Australian model of women's policy machinery was that it was originally developed by the women's movement rather than invented by government. Members of the Women's Electoral Lobby (WEL) inside and outside government worked on a model for women's machinery, which they presented to the Royal Commission on Australian Government Administration set up by the Labor government in 1974. The model consisted of a women's coordination unit within the central policy coordinating agency of government linked to a network of departmental women's units responsible for monitoring policy at the point of initiation. This kind of women's movement debate over the most effective form of government 
machinery was absent at the time in comparable countries such as Canada (Arscott, Rankin and Vickers, 1997).

Australian feminists decided against a self-standing bureau or ministry on the grounds that it might simply become a 'waste-paper basket for women's problems' and an alibi for gender-blind policy in the rest of government. It was also perceived that a self-standing ministry would lack policy clout and have difficulty in accessing crucial Cabinet submissions and Cabinet processes. Location within the Prime Minister's portfolio made access to Cabinet and coordinating work across government much easier. In order to strengthen gender advocacy within Cabinet itself, a minister assisting the Prime Minister for the status of women was subsequently appointed, briefed by the women's unit within the Prime Minister's department. After some misadventures, including exile in a low-ranking portfolio, the Office of the Status of Women (OSW) returned to the Prime Minister's Department in 1983.

While women's coordination units such as OSW focused on across-the-board gender analysis of policy rather than programme delivery, they were also responsible for coordinating cross-portfolio initiatives and for the development of new policy to the point where it could be handed over to another agency for implementation. Examples of the latter at the federal level were the development of federal sex discrimination and affirmative action legislation. Femocrats inside and outside OSW also influenced policy over a range of sectors at this time - such as the quintupling of the national child-care programme; the development of the home and community care programme; increased funding of women's services; improved access of women, including married women and sole parents, to labour market assistance; shifting of family support to primary carers; and national programmes on violence against women and women's health. Where government could not be swayed from policy directions disadvantaging women, such as the reintroduction of fees for tertiary education or the introduction of enterprise bargaining instead of centralized wage fixing, there were policy 'saves' to try to minimize their impact.

The Australian model of women's policy machinery was not only developed by feminists, it was even justified in terms of the compatibility of the matrix structure with the 
women's movement's philosophy. Undoubtedly, however, the location of the central unit within the central policy arena made the modelling of the feminist process more difficult, if not impossible. Hence the paradox that it was 'sisters in suits' who acted as the internal advocates for the funding of the quite unconventional models of service delivery developed by the women's movement (Eisenstein, 1995).

Mediation by femocrats both in coordinating and line departments contributed to the ability of women's services to resist pressure to become conventional service deliverers and to persist in modelling feminist organizational forms. Most women's services, such as refuges, domestic violence referral services, women's health centres, rape crisis centres, women's legal centres and working women's centres, were government funded but largely run on semi-collectivist lines by community-based groups. Representatives of such services were brought into policy advisory bodies and played an important role in policy development and law reform. Governments themselves took on the responsibility of providing women's information services from the 1970s, but these were shaped by the organizational philosophy of the community-based women's services.

Another Australian innovation was the women's budget process. This was a major coordinating exercise, pioneered at the federal level in 1984, whereby all departments and agencies were required to account for the impact of their activities on women in a budget document. The Women's Budget Program was a world first in terms of educating bureaucrats to disaggregate the impact of their 'mainstream' programmes rather than simply highlighting programmes for women. Many departments had not previously collected data relating to their programmes on a gender basis. The idea of insisting on gender disaggregation of budgetary outlays was an inspired one. In one state it was found that specifically targeted allocations to women and girls in the community made up only 0.75 per cent of global budgets (Sharp and Broomhill, 1990:3). This meant that it was the disaggregation of general outlays that was crucial to see who benefited from government activity.

Departments were not allowed to escape with unsubstantiated claims that because their policies were directed 
towards some public benefit such as the health of the economy that they would therefore have the same impact on men and women. They were required to maintain sexdisaggregated statistics relevant to policy and programmes. The need to examine the different location of men and women in the labour market in order to assess the impact of industry restructuring, for example, was a useful lesson for bureaucrats in how rare it is for public policy to be gender neutral in its effects.

The idea of the women's budget programme was to be an attractive one for feminists in other countries trying to mainstream gender accountability and the (British) Commonwealth Secretariat is now assisting countries interested in developing pilot women's budget programmes (Budlender and Sharp, 1998).

In taking up this Australian model, other countries have improved upon it, for example by the incorporation of parliamentary oversight (a parliamentary committee with some expert technical support) to ensure it remains a meaningful accountability exercise. In Australia, the federal prototype became 'captured by the bureaucracy' and became more a public relations exercise concerned with specific initiatives for women than the intended longitudinal analysis of progress in improving gender equality within mainstream programmes. By 1998, the women's budget had been abolished at the federal level and in most jurisdictions. It was not replaced, as recommended in 1993, by the inclusion of gender-reporting requirements within the format used for budget reporting to Parliament.

WEL lobbied for the original model of women's policy machinery to be adopted by state and territory governments and it was eventually replicated in all jurisdictions, including the women's budget process. The quarterly meetings of federal, state and territory women's advisers inaugurated in 1978 helped to ensure that best practice from whichever government was picked up and reproduced. These meetings were originally off-the-record exchanges of strategic information by feminists and were unlike other intergovernmental meetings. This changed with the establishment of the Ministerial Conference on the Status of Women in 1991, after which the officials' meetings took on more familiar traits of political competitiveness. Today the 
intergovernmental arrangements for women's policy are far from satisfactory.

As already noted, location in a central policy area was a drawback in terms of feminist process; the confidentiality of policy advice at Cabinet level caused tensions with nongovernmental organizations (NGOs) expecting more sisterly sharing of information. Nonetheless, policy success was most likely when there was joint work from inside and outside government, as with the eventual ratification of the International Labour Organization Convention 156 on Equal Opportunities for Workers with Family Responsibilities in 1990.

Under the federal Labor governments of the 1980s and 1990s, bureaucratic monitoring of policy was reinforced at the political level by the Parliamentary Labor Party (Caucus) Status of Women Committee, meeting weekly. There was no multi-party parliamentary committee with oversight of bureaucratic forms of gender accountability (e.g. requirements relating to annual reports, preparation of estimates or budget documents).

To summarize, the characteristics of the Australian model at its best were as follows:

- location of the central unit in the chief policy coordination agency;

- Prime Minister taking portfolio responsibility, assisted by a woman Cabinet minister;

- focal points in other government agencies;

- emphasis on gender audit through analysis of Cabinet submissions and budget outlays;

- reinforcement of bureaucratic monitoring by a parliamentary party committee;

- funding of women's advocacy groups as well as women's services;

- community representation on policy advisory bodies;

- use of intergovernmental bodies to share best practice.

\section{Diversification and/or disappearance}

In this context of unfavourable ideological and political shifts, it is perhaps not surprising that the original Australian 
model of women's policy machinery, with its strengths and weaknesses, no longer exists. Instead, there has been diversification of structures, ranging from almost complete disappearance in the Australian Capital Territory to the creation of a self-standing Department for Women in New South Wales. ${ }^{2}$ In this section, I draw on structural issues nominated by members of the Standing Committee of Commonwealth/State Women's Advisers during a workshop in February $1998 .^{3}$ The section is biased towards subnational issues.

A major issue for women's advisers is that of location in all states the variously named women's policy coordination units have been moved out of the central location they originally enjoyed. In addition to the loss of central location and the authority of the Premier, there have been the mobility costs of following ministers to different portfolios. Movement out of Premier's Departments also raises the issue of Cabinet seniority of the minister or, in the worst case, location of that minister outside Cabinet.

Another major issue in the context of a federal system, and one related to the location issue, is the accessibility and accountability of intergovernmental bodies responsible for financial arrangements and programme coordination. The lack of effective gender input into intergovernmental agreements has become increasingly evident, with Premier's and Treasury Departments playing the predominant role. The Ministerial Conference on the Status of Women has very limited influence on other ministerial councils, in particular on the Council of Australian Governments or its predecessor, the Special Premiers' Conferences. This is a matter of considerable concern when decision making is moving out of the public domain into these 'closed door' intergovernmental bodies. In 1991 the Ministerial Conference did attempt to query the gender impact of 'new federalism' proposals that would have untied Commonwealth grants in areas such as community services, health and housing. By the mid 1990s, however, major new intergovernmental agreements, such as those underpinning competition policy, received little contestation from this quarter. A paper on the gender implications of competition policy did not go to the Ministerial Conference until two years after the competition policy agreements had been signed. 
The women's sub-committees that advised ministerial councils in areas such as health, housing, education, employment and training have also been allowed to wither on the vine. The new push to devolve Commonwealth responsibilities in areas such as health and to untie funding for specific programmes such as the National Women's Health Program and the Alternative Birthing Services Program has been accompanied by the decision to abolish the Women's Health Sub-Committee of the Health Ministers' Advisory Council (from October 1998). While the focus on gender audit of policy and programme delivery had been seen as a strength of the Australian model, it has not extended to the increasingly important intergovernmental arena.

Another problem for women's policy structures is a more general issue arising from the nature of the new public sector management - the increased volatility of bureaucratic structures and the environment of continuous change. Within this environment it is difficult to sustain the structures needed for long-term projects such as improving the status of women and there is a continuing loss of corporate memory. Moreover, within the commercial product format and outcomes focus associated with the new public sector management there is a devaluing of process, including the information sharing that has been central to feminist work.

Also related to the new public sector management is the devaluing of policy expertise of all kinds, including the expertise in gender analysis necessary if policy is to be adequately evaluated at source for gender impact. Such expertise is also needed for the purpose of accountability. Without adequate means of external accountability, including requirements for disaggregated statistical data, gender 'mainstreaming' will not take place. Accountability through performance agreements between chief executive officers and ministers, without an external element, is unlikely to result in such expert scrutiny. Too often 'mainstreaming' becomes a code word for killing off gender audit.

Another topical issue is the need for more effective use of information technology to improve the interface between women's policy structures across and between governments and between women's policy structures and women in the community. At the time of the February 1998 workshop, many women's policy units lacked web links to women's 
policy areas in other portfolios or levels of government or to women's policy units in the Asia-Pacific region. There have been some improvements since the workshop - for example, the federal rural women's website installed excellent links to other federal and state women's units as well as NGO sites. There is also now some participation by feminist bureaucrats in Ausfem-Polnet, the main electronic feminist policy discussion list in Australia.

A longstanding issue in women's affairs has been the lack of a consistent approach to creating a 'national voice for women' in public policy debate to ensure that gender perspectives are always heard on policy issues of the day. Alternatives that have been pursued in a half-hearted manner are: strengthening the forum which links women's advisory councils from the different jurisdictions and supporting greater coordination among women's NGOs through funding networking or peak bodies as in other sectors.

International work on state feminism (e.g. Stetson and Mazur, 1995) suggests that one of the most important functions of women's policy machinery is making resources available to community organizations, including funding, information and access to the policy process. Today, governments often express doubt that community organizations are really representative of women and prefer to engage in market research to test women's attitudes to government policies. This is far from the citizenship empowerment or capacity-building model of the past and seeks to bypass the mediated expression of women's views.

A different issue is the need to clarify the relationship between advisory and policy structures. Incoming governments sometimes place more trust in 'their' women, who they can place directly on advisory bodies. Partisan bias in appointments to advisory bodies contributes to failure to develop bipartisan support for women's policy structures, quite apart from the issue of appropriate functional roles. By contrast, where there is broad political representation on advisory bodies, this can act as a parachute for internal women's policy structures during a change of government.

State women's advisers have also raised the importance of 'international learning' - of borrowing approaches to gender mainstreaming that have been successful elsewhere. Such international borrowing or 'model mongering' can give 
a strategic advantage to those otherwise low in power resources (Braithwaite, 1994). If it can be argued that something has worked in the European Union or Canada, this can provide significant leverage in Australia. As discussed further below, international instruments and associated reporting requirements are another important resource.

\section{Changes at the federal level between 1996 and 1998}

Some of the broader changes occurring in women's affairs have been sketched above. This section deals with more specific changes that have occurred at the federal level since the election of the conservative coalition government in March 1996. This government was elected with promises to end the reign of 'political correctness' and to 'govern for the mainstream'. In line with the general delegitimizing of equity agendas, OSW suffered a budget cut of 40 per cent in 1996, quite disproportionate to the rest of the Prime Minister's portfolio. The cut in staff numbers and the departure of all but eleven of the former staff during the accompanying demoralization affected all aspects of the Office's work. A new Head was appointed to the Office with no background in the women's movement or policy experience. A radio journalist, she was co-author of a very flattering biography of the Prime Minister.

As a result of the 1996 budget cut, OSW was no longer able to provide its share of funding for the Women's Statistics Unit in the Australian Bureau of Statistics, which consequently closed in June 1997. The Unit had produced Women's Year Books since 1994, replacing the gender equality indicators used previously to measure outcomes of government activity to advance the status of women. Both forms of statistical monitoring had received favourable international attention. At the same time another form of gender audit, the federal women's budget process, was finally abolished completely. As noted above, it was not replaced by the requirement for gender accountability in estimates reporting, as originally intended.

Abolition of the women's budget process was accompanied by a more general withdrawal by OSW from a role 
in coordinating or supporting women's policy work across government. Its new self-description in the Commonwealth Government Directory referred only to its role in providing strategic advice on specific areas of policy, not to any role in mainstreaming gender perspectives. By default, coordination initiatives tended to come from elsewhere.

The minister assisting the Prime Minister for the status of women was one of the most conservative members of the government, Senator Jocelyn Newman, known for the confrontational style she adopted towards NGOs. After a brief period during which a junior minister was Minister for the Status of Women, Newman resumed portfolio responsibility in 1998. The following year she allocated $\$ 100,000$ (over two years) in operational funding to a men's rights group, Lone Fathers' Association Australia.

Newman announced the funding of Lone Fathers at their national conference, saying it was 'to redress the gender imbalance in policy development'. In this, she echoed men's rights discourse, which positions men as victims of allpowerful bureaucratic feminism. A couple of weeks later, Newman announced the defunding of the National Council of Single Mothers and Their Children. These moves were particularly controversial as they mirrored the government's amendments to the Child Support Scheme, which reduced transfers to custodial parents and increased control of noncustodial parents over the remaining transfers. Newman was subsequently forced by public furore to refund single mothers.

In the meantime, the funding for women's NGOs was reduced by half (to $\$ 500,000$ per annum) and by 1999 operational funding was provided only to more conservative and less policy active NGOs. Under the new regime, the ministerial round tables (meetings between national women's NGOs and government ministers) were reduced in frequency from twice to once a year, and agendas were much more closely controlled by government. The information-sharing network set up by national women's organizations to coordinate advocacy work (and input into round tables) was defunded and replaced, after a tendering process, by a commercially provided and inferior website.

Round tables are a common form of consultation in Australia, with NGO representatives being paid to come to 
Canberra to attend. This enables face-to-face meetings between NGO representatives before the meetings with government, something much prized in a country where distances make such face-to-face meetings difficult. In 1999 the majority of national women's NGOs (some forty out of sixty) received letters 'disinviting' them from the round table, being informed that selected 'prominent individual women' would be invited in their place.

Meanwhile, the fate of women's policy structures across federal portfolios varied markedly. The Department of Education, Training and Youth Affairs provided the worstcase scenario, with the loss of all its women's policy structures, including its Women's Bureau dating from 1963. The Women's Bureau had already been fatally weakened by a 'mainstreaming' exercise under the previous government and it was finally abolished in 1997. Its research funding programme, the Women's Research and Employment Initiatives Program, dating from 1984, was also abolished.

As can be seen from Figures $3(\mathrm{a})$ and $3(\mathrm{~b})$, another loss was the Office of Indigenous Women in the Aboriginal and Torres Strait Islander Commission (ATSIC) - responsibility for women was to be 'mainstreamed' to programme managers and to the one remaining officer with responsibility for the Indigenous Women's Issues Program. Meanwhile, the Work and Family Unit and the Equal Pay and Workplace Relations Section in the Department for Workplace Relations and Small Business survived and even grew during the period, thanks to particularly dedicated and skilful bureaucrats. Policy monitoring in these areas was of major importance because of the effects of 'workplace reforms' (shifts to decentralized wage bargaining) on family-friendly hours and pay relativities.

The Work and Family Unit oversees the Working Women's Centres set up to provide assistance to women workers under the more decentralized wage-bargaining system. The Centres were also intended to be an important source of policy input, but under the coalition government they no longer receive operational funding and so are too busy chasing government contracts.

The Equal Pay Section acquired extra temporary staff because of its responsibility for servicing an independent review of the Affirmative Action Act, one of a series of 
Figure 3(a) Federal women's policy machinery, February 1996

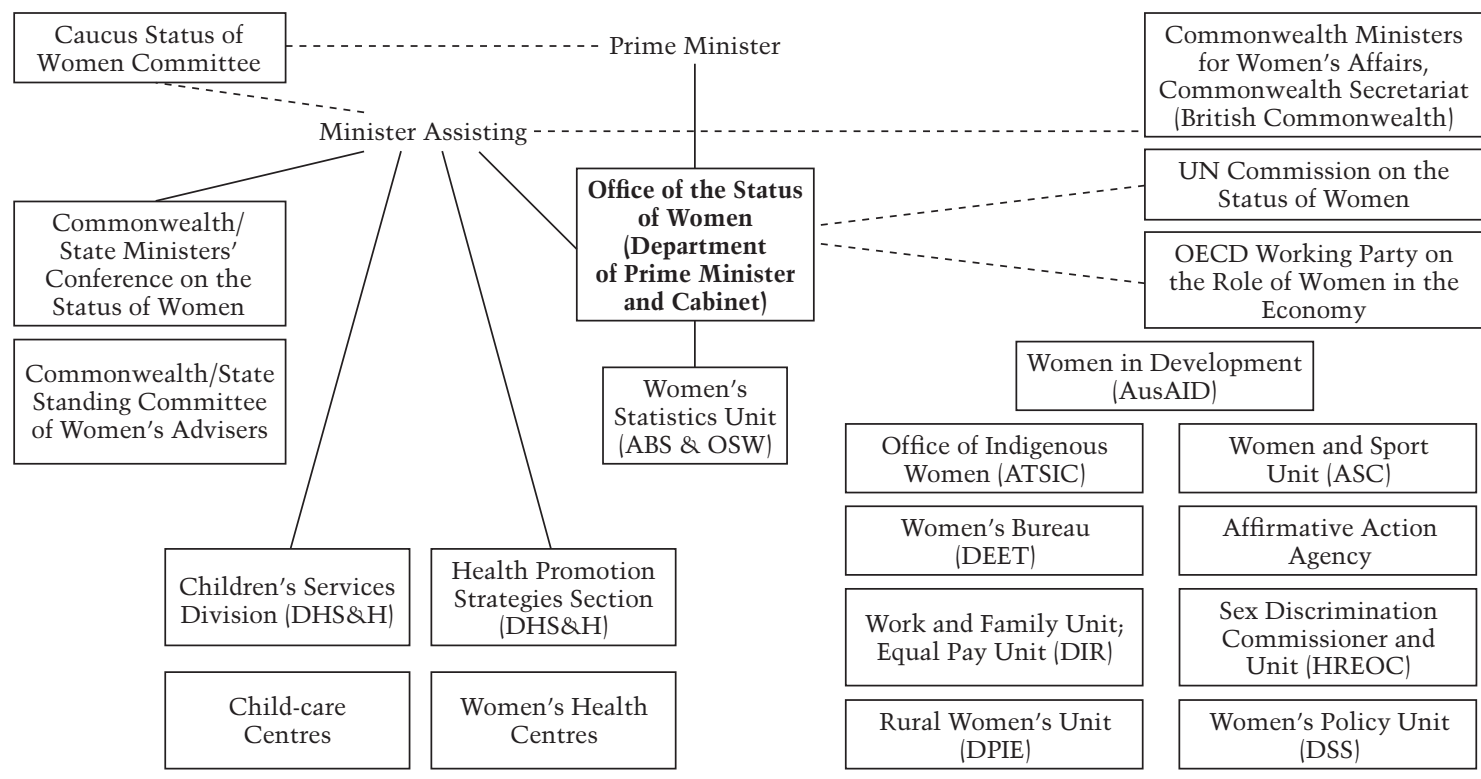

Key: ABS - Australian Bureau of Statistics; ASC - Australian Sports Commission; ATSIC — Aboriginal and Torres Strait Islander Commission; AusAID - Australian Agency for International Development; DEET — Department of Employment, Education and Training; DHS\&H - Department of Human Services and Health; DIR — Department of Industrial Relations; DPIE — Department of Primary Industries and Energy; DSS — Department of Social Security; HREOC - Human Rights and Equal Opportunity Commission; OECD — Organization for Economic Cooperation and Development. 
Figure 3(b) Federal women's policy machinery, September 1999

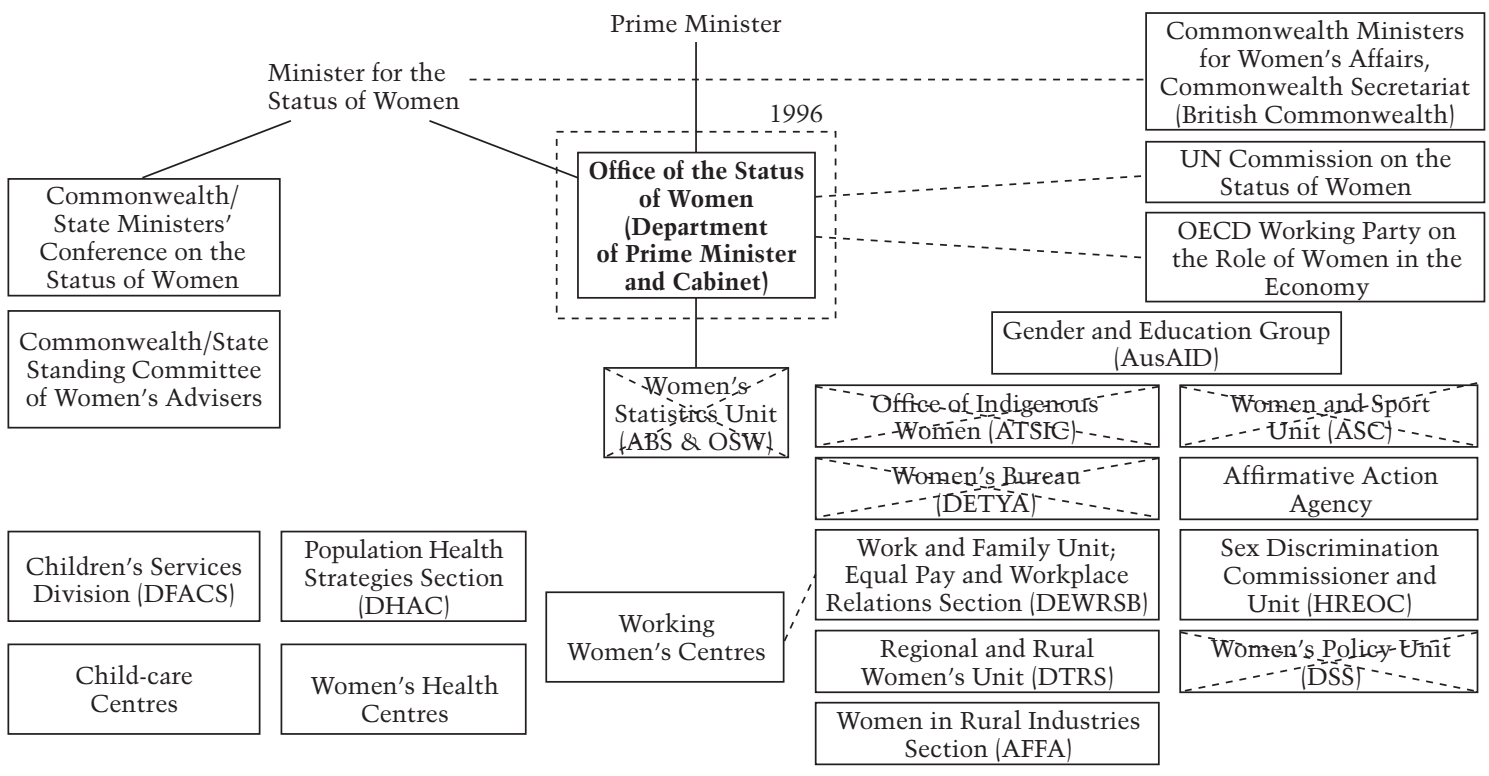

Key: ABS - Australian Bureau of Statistics; AFFA - Agriculture, Fisheries and Forestry-Australia; ASC - Australian Sports Commission; ATSIC Aboriginal and Torres Strait Islander Commission; AusAID - Australian Agency for International Development; DETYA - Department of Education, Training and Youth Affairs; DFACS — Department of Family and Community Services; DHAC — Department of Health and Aged Care; DEWRSB Department of Employment, Workplace Relations and Small Business; DTRS - Department of Transport and Regional Services; HREOC — Human Rights and Equal Opportunity Commission; OECD — Organization for Economic Cooperation and Development. 
regulatory reviews required by the 1995 intergovernmental Competition Policy Agreement. Unexpectedly, the review was very positive and recommended strengthening the powers of the Affirmative Action Agency. The response of the federal government was, however, lukewarm. Many believed the view of the government had been signalled by a letter sent to ministers on 30 April 1997 telling them that departments should not deter the private sector by drawing attention to the need for government contractors to be in compliance with the Affirmative Action Act.

In the Australian Sports Commission, the Women's Sports Unit was gradually whittled away under the new government, finally disappearing completely in 1999. In the same year, the main NGO in the area, Womensport Australia, was also defunded.

While much of the impact of the federal coalition government on women's policy machinery was negative, an exception was the rural affairs area, where policy advisory and consultative arrangements were expanded. The coalition government included the rural-based National Party, under threat from the rise of rural-based populism and anxious to shore up its constituency. During 1996-98 the Rural Women's Unit in the Department of Primary Industries and Energy increased in size and initiated new consultative arrangements bringing together senior policy makers and rural women's NGOs.

After the 1998 federal election, portfolio restructuring resulted in the renamed Regional and Rural Women's Unit migrating with its National Party minister (now Party Leader) to the Department of Transport and Regional Services. A round table with NGO women in mid 1999 was notable for the fact that, unlike the recent round tables serviced by the Office of the Status of Women, the minister actually listened to NGO women. Shortly afterwards a Regional Women's Advisory Council was established, headed by the energetic President of Australian Women in Agriculture (a leading NGO).

A new women's unit called the Women in Rural Industries Section was also established in the Ministry of Agriculture, Fisheries and Forestry - Australia. This unit inherited the Women in Rural Industries NGO grants programme established in 1998, which provided operational 
funding to two NGOs in 1999 and seed funding for another.

An isolated example of a new intergovernmental structure being created during this period is the Australasian Women in Policing Advisory Committee, which has a mandate to advise Police Commissioners on gender issues.

Meanwhile, the Human Rights and Equal Opportunity Commission had been less fortunate - between 1997 and 1999 its budget was reduced from $\$ 19.3$ million to $\$ 12.3$ million - a decrease of 36 per cent over the two years and quite disproportionate in relation to the rest of the Attorney-General's portfolio. The cuts meant the halving of the staff in the Sex Discrimination Unit - although, in fact, turnover was almost complete as a result of demoralization. Moreover, the statutory position of Sex Discrimination Commissioner was left vacant for a year while the government considered abolishing it along with the other specialist Commissioners. This meant not only a policy hiatus in 1997-98, but also a loss of visibility. Other matters of concern included future accessibility of remedies under a new and expensive federal court regime and large cuts to legal aid. Symptomatically the Human Rights branch of the Attorney-General's Department also lost the bulk of its staff at this time.

Under the new federal government, there was a loss of political as well as bureaucratic accountability, with no backbench committee on the status of women. This was explained in terms of the very divergent views among coalition women MPs, from feminists to outspoken antifeminists as well as individualist philosophies, limiting the possibilities of collective work. The lack of collective strength was very evident as government cuts left children's services in crisis.

\section{The international dimension}

Historically, Australian feminists have put considerable effort into international work. The development of international instruments and platforms has provided an important form of domestic leverage, both through international 
standard setting and related reporting processes (see Sawer, 1998). Usually there has been close cooperation between NGOs and femocrats over international status-of-women issues. The Australian women's movement has rarely been involved in the kind of politics of embarrassment or international shaming that has been part of the repertoire of other social movements.

More recently, the women's movement has felt pushed into an oppositional stance at the international level, most notable on the occasion of Australia's presentation of its periodic report to the Committee on the Elimination of Discrimination Against Women (CEDAW) in July 1997. A joint NGO report was prepared and seventeen organizations were signatories to it. ${ }^{4}$ A representative travelled to New York and briefed CEDAW members over lunch the day before Australia's report was presented.

NGOs had not been consulted, as in the past, over Australia's official report, which was not, in fact, a proper periodic report at all. It was the resubmission of supplementary material provided at the time that Australia's Second Report was considered in 1994. The information had been rendered very out-of-date by the change of federal government.

The NGO report detailed, as the official report did not, the policy impact of the new federal government in areas of special concern to women. This was also covered in a report prepared for CEDAW by the Federal Labor Party Status of Women Committee entitled 'Back to the 1960s? Progress Report on the Australian Government's CEDAW Obligations and Beijing Platform for Action' (Coalition of Australian Participating Organizations of Women, 1997).

The subsequent comments by CEDAW on the Australian official report were a far cry from those when Australia had presented its first report. In 1988, the Australian report was described as exemplary in terms of both the substance of machinery and programmes it described and its self-critical nature. In 1997, Australia was criticized by CEDAW for its retreat from international leadership on gender equality issues and for the erosion of women's policy structures at home (CEDAW, 1997).

In expressing concern over the government's apparent shift in attention away from gender equality and the 
weakened role of national machinery, CEDAW specifically noted the abandonment of initiatives such as the women's budget statement and the Register of Women, which had served as models for other governments. It also expressed concern over the consequences for women of policy changes affecting child care, housing and labour market assistance. The Committee recommended that the government carefully monitor the impact of recent policy changes for the purpose of its next periodic report, including an evaluation of the impact of the new decentralized wage-fixing system on different groups of women and the impact of the shift in responsibility for health care from the federal to the state level. As we have seen, the mechanisms for performing such a role have been eroded at the intergovernmental level as well as within Australian governments.

CEDAW's criticisms of the Australian government's retreat on gender equality received wide media coverage and in turn provoked a furious reaction from the government. The Minister Assisting the Prime Minister on the Status of Women slammed NGOs for 'bagging their country from overseas'. The government's operational funding for the NGO network, the Coalition of Australian Participating Organizations of Women, which had helped to initiate the NGO shadow report, expired on 30 June 1997 and was not renewed. ${ }^{5}$

Unfortunately, the coalition government appeared less interested than its predecessors in its international reputation in Human Rights areas, as exemplified by the cavalier attitude adopted towards findings by the Human Rights Committee that it was in breach of the International Covenant on Civil and Political Rights (Evatt, 1988). So just when the women's movement has been mobilized to use the shaming tactic, it has become less effective. Nonetheless, there were some effects, including a backdown over the position of Sex Discrimination Commissioner.

\section{Conclusion}

The structures for gender accountability within government, which Australia helped to pioneer, have been threatened by 
discursive shifts within the government. Women have been discursively repositioned as a 'special interest group' rather than as a majority of citizens with legitimate claims on government. Processes for promoting gender equality in policy design and service delivery have been recast as a form of rent seeking as well as an obstacle to international competitiveness.

At a broader level, ruling concepts now include those of 'competition' (reducing the role of the public sector) and 'micro-economic reform' (reducing the role of unions and centralized wage fixing). In the face of these fundamental shifts away from Australia's historical traditions, feminists have been successful only in establishing some monitoring and mitigating regimes. And at the intergovernmental level, which has become increasingly important in terms of framework agreements, feminists have had even less success.

Nonetheless, women's policy machinery still exists in most Australian jurisdictions and, where it has been abolished, the government is often very coy about the fact (e.g. suggesting that women's policy functions are still being carried, even if there are no longer dedicated positions for this purpose). A number of governments have recently changed and national NGOs have been considering what machinery improvements they would like to see under a new federal government. Discussion of such issues is very important in creating a sense of ownership and a political base for them in the women's movement. Suggestions include the greater use of the Australian National Audit Office in auditing the mainstreaming of gender accountability in government and a return to some form of gender accountability in budgetary reporting to Parliament. Another issue is how to increase gender accountability in the intergovernmental arena, where important framework decisions such as competition policy are now being made.

One machinery possibility is a (multi-party) parliamentary standing committee on the status of women. Such a committee would oversee requirements for gender accountability in, for example, annual reporting to Parliament and in budgetary reporting, and would require a secretariat with technical expertise in gender analysis. The main problem with such a proposal in the Australian context is the very adversarial nature of the party system and the fact that it is 
the Labor Party that has been more identified with supporting gender accountability than the coalition parties. It could be argued that such a multi-party body would help to educate all participants in the unintended gender effects of policy making; if so, it would be a triumph over current ideological positions.

In terms of NGO input into policy making, one important decision is whether to support the existence of women's advisory bodies, serviced by government, or whether money is better spent supporting community-based peak organizations independent of government. Women's advisory bodies, serviced by women's policy units, have played an important role as a public voice for issues on which femocrats cannot speak out. When carefully constituted they have also helped to broaden awareness and political support for women's policy machinery (the parachute function). On the other hand, advisory bodies are inevitably constrained by government agendas and are frequently frustrated in their attempts to establish greater independence.

The lessons from the Australian experience are not wholly negative. Despite the unfavourable discursive shifts, there is still institutionalized acknowledgement that all government policy needs to be analysed for gender effects and that no policy can be assumed to be gender neutral. This has now been in place for twenty-five years. And, as in the past, Australian women will look to multilateral forums to help provide the impetus for further progress. The relationship between domestic and international work on the status of women in Australia has been a close one. Both the League of Nations and the United Nations have played an invaluable role in standard setting for us, a process in which we have participated as both agents and beneficiaries.

\section{Notes}

1 With thanks to Lani Russell for the 1998 survey of federal women's policy units and to Sarah Miskin for editing.

2 In the Australian Capital Territory, policy units were 'mainstreamed' in the mid 1990s, leaving only the Women's Information and Referral Service and a Women's Consultative Council. As of June 1998, New South Wales had the best staffing for its women's policy machinery of 
any jurisdiction - for example, fifty-two staff in the Department for Women and ten in the Women's Equity Bureau (Department of Industrial Relations).

3 The workshop, entitled 'The Future of Women's Policy Structures in Australia', was held on 12 February at the Research School of Social Sciences, Australian National University, and was attended by Women's Advisers from all jurisdictions including New Zealand but excluding the Commonwealth.

4 The signatories to the NGO report were as follows: Association of Non-English Speaking Background Women of Australia; Australian Feminist Law Foundation; Australian National Committee on Refugee Women; Australian Reproductive Health Association; Australian Women Lawyers' Association; Bahai Office for the Advancement of Women; Coalition of Activist Lesbians; Coalition of Women's Right to Choose; International Women's Development Agency; National Pay Equity Coalition; National Women's Media Centre; School of Women Artists; United Nations Association of Australia Status of Women Committee, SA; Women's Economic Think Tank; Women's Electoral Lobby Australia; Women's International League for Peace and Freedom; Young Women's Christian Association of Australia.

5 Other 'peak' bodies defunded following criticism of coalition government policies included the Australian Pensioners' and Superannuants' Federation, National Shelter, and the Australian Youth Policy and Action Coalition. 
Marian Sawer - 9781526137494

Downloaded from manchesterhive.com at 04/25/2023 11:57: $08 \mathrm{PM}$ 